\title{
Combining Chemical and Biological Catalysis for the Conversion of Hemicelluloses: Hydrolytic Hydrogenation of Xylan to Xylitol
}

\author{
Gerd Hilpmann ${ }^{1}$ - Susanne Steudler ${ }^{2}$ - Mick Miro Ayubi ${ }^{1} \cdot$ Arne Pospiech $^{1} \cdot$ Thomas Walther $^{2} \cdot$ Thomas Bley $^{2}$. \\ Rüdiger Lange ${ }^{1}$
}

Received: 20 July 2018 / Accepted: 21 October 2018 / Published online: 29 October 2018

(c) The Author(s) 2018

\begin{abstract}
The conversion of xylan to xylitol is commonly realized via the two separate process steps hydrolysis and hydrogenation (or fermentation). Recent research activities aim at developing one-pot processes to facilitate this conversion to save resources and operation time. To avoid hazardous chemicals like liquid acids for the initial xylan hydrolysis, enzymes are a suitable green alternative. A series of experiments are discussed wherein process conditions for chemical conversion were adjusted to more enzyme-friendly reaction conditions to overcome xylose-induced product inhibition by direct hydrogenation of sugar to xylitol. A novel combination of enzymes and precious metal catalyst $(\mathrm{Ru} / \mathrm{C})$ in an one-pot process is demonstrated. Based on these results, limiting factors and potentially advantageous process parameters as well as catalyst combinations are discussed.
\end{abstract}

\section{Graphical Abstract}

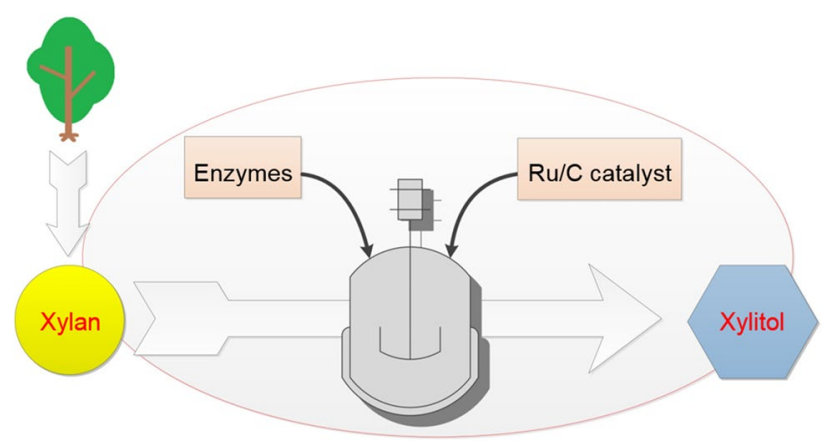

Keywords One-pot process $\cdot$ Xylan $\cdot$ Xylitol $\cdot$ Green chemistry $\cdot$ Xylanases $\cdot$ Hydrolytic hydrogenation $\cdot$ Bio-chemo catalysis

This paper is dedicated to the 60th birthday of Tapio Salmi.

Gerd Hilpmann

gerd.hilpmann@tu-dresden.de

Susanne Steudler

susanne.steudler@tu-dresden.de

Mick Miro Ayubi

mick_miro.ayubi@tu-dresden.de

Arne Pospiech

arne.pospiech@web.de

Thomas Walther

thomas_walther@tu-dresden.de
Thomas Bley

thomas.bley@tu-dresden.de

Rüdiger Lange

ruediger.lange@tu-dresden.de

1 Chair of Chemical Engineering and Process Plants, Institute of Process Engineering and Environmental Technology, Technische Universität Dresden, 01062 Dresden, Germany

2 Chair of Bioprocess Engineering, Institute of Natural Materials Technology, Technische Universität Dresden, 01062 Dresden, Germany 


\section{Introduction}

Today's society aims at switching from fossil resources to renewables in almost any imaginable way. Very prominent examples are energy harvesting from wind, solar power and biomass. However, the chemical industry still relies strongly on fossil resources for the production of platform and fine chemicals. Research activities in the field of converting lignocellulosic (plant) biomass have therefore focused more and more on the conversion to value-added products [1-4] in contrast to the state-of-theart conversion to biobased fuels [5]. Lignocellulosic biomass of agricultural origin typically consists of $10-25 \%$ lignin, $20-30 \%$ hemicelluloses and $40-50 \%$ cellulose. In contrast, lignocellulosic material from hardwood (forest and pulping industries) contains 18-25\% lignin, 24-40\% hemicelluloses and $40-55 \%$ cellulose [6].

Until today, the use of hemicelluloses as a feedstock for microbial product synthesis plays a subordinate role due to their heterogeneous and complex structure. Hemicelluloses include glucuronoxylan, arabinogalactan, and other galactans, mannans and xylans dependent on the plant source. Xylan is a group of hemicelluloses typically found in hardwoods made from $\beta$-1,4-linked xylose units which can be hydrolyzed to xylose. Commonly, hemicelluloses are converted via mechanical and thermo-chemical pretreatment followed by chemical or enzymatic cleavage. An industrially relevant chemical process is hydrolysis with dilute acid $(2-5 \mathrm{v} / \mathrm{v}-\%)$ at $160-230{ }^{\circ} \mathrm{C}$ and a pressure of 10 bar [7]. In addition, recent research showed that liquid acids might be replaced by solid acidic catalysts in the near future $[8,9]$. Alternatively to chemical treatment, enzymes can be used to specifically convert hemicellulose bound in lignocelluloses to monomers at mild conditions (pH 5, temperature $45-50{ }^{\circ} \mathrm{C}$, atmospheric pressure). An advantage of enzymatic versus chemical hydrolysis is the absence of acidic (or base) chemicals, which can greatly reduce downstream efforts that would typically include neutralization and/or separation of those chemicals. Enzymes are also known for their high selectivity, hence decreased formation of undesired byproducts or inhibitors. Last but not least, enzymatic catalysis is typically (and rightly) associated with lower requirements in process safety and less energy consumption.

Enzymatic cleavage of xylans requires several different hydrolytic enzymes due their high variability and heterogeneous structure. These enzymes typically include endo-1,4- $\beta$-xylanase, $\beta$-xylosidase, $\alpha$-glucuronidase, $\alpha$-L-arabinofuranosidase and acetylxylan-esterase, and are usually assorted as xylanases [10]. They are divided into different groups, depending on molecular weight and sequence of amino acids. The different glycoside hydrolase
(GH) species are: 5, 8, 10,11, 16, 26, 30, 43 and 62. The main groups are GH10 and GH11 (due to their familiarity of amino acid sequences), while GH11 exhibits higher substrate selectivity, increased catalytic efficiency and a broader $\mathrm{pH}$ - and temperature optimum [10, 11].

During the proceeding of hydrolysis new covalent bonds become accessible for the enzymatic cleavage, causing a stepwise release of (xylo-) oligomers and subsequent monomers (xylose) as product. Endo-Xylanase is responsible for the cleaving of the bulk structure into oligomers, hence facilitating access for all other applied enzymes. The xylan is finally converted into monomers via the subsequent activity of $\beta$-xylosidase and the sidechain-cleaving enzymes.

One of the most attractive products that can be derived from xylose is xylitol. Xylitol (E 967) is a sugar substitute that has high sweetening power, anti-cariogenic effects and an insulin-independent metabolic pathway [12]. Currently, it is not possible to cover the demand on the market due to the limited, complicated and costly production [7]. Conventionally, xylitol is produced via hydrogenation over Raney-nickel-catalysts at $80-130{ }^{\circ} \mathrm{C}$ and $40-70$ bar [13]. The yields in this process are $50-60 \%$ based on xylan, but only $8-15 \%$ based on lignocellulose [7]. In addition to negative environmental aspects caused by nickel, the process is costly and energy-intensive due to a high number of required purification steps and the need for at least two separate reactors (subsequent cleavage and refinement). More environmentally friendly, xylitol can be gained through enzymes or microorganisms, especially Debaryomyces hansenii or yeasts of the species Candida sp [14]. Theoretical yields of $80 \%$ were reported, but the volumetric productivities are still low and the process is rather slow.

In theory, a pure enzymatic conversion of xylan to xylitol is possible, however biocatalysis does not come without drawbacks that are imposed by e.g. storage and handling issues, long process durations and inhibition by various sources. One of the most disadvantageous factors is the xylose-induced product inhibition of the enzymatic hydrolysis, which strongly limits the product yields. To avoid the accumulation of inhibiting xylose concentrations, enzymatic hydrolysis was combined with direct hydrogenation of xylose to xylitol by chemical catalysts.

While this approach appears to be conceptually straight forward, implementation of such a process requires a suitable process parameter window in which both catalytic reactions work in an efficient manner. In the present work we have investigated limiting factors and potentially advantageous process parameters as well as different catalyst combinations. For that, a series of experiments is discussed wherein process conditions for chemical conversion were adjusted to more enzyme-friendly reaction conditions to overcome xylose-induced product inhibition by direct hydrogenation of sugar to xylitol in an one-pot process. We found a novel 
combination of enzymes and precious metal catalyst $(\mathrm{Ru} / \mathrm{C})$ as well as suitable process conditions which demonstrate the possibility of combination of bio- and chemo-catalysis in the same one-step process and reactor for the simultaneous hydrolysis and hydrogenation.

\section{Experimental}

\subsection{Setup}

The experiments were carried out in a stainless steel batch reactor (Parr Inst.) with an inner volume of 300-600 ml. Reactor heating was realized via external thermostat (Julabo) connected to the reactor's jacketed vessel. The pressure for the hydrogenation process was applied via gaseous hydrogen from an orifice in the reactor head. A gas entrainment stirrer was used for optimal gas supply and mixing of the reaction solution at maximum stirring speed of $1000 \mathrm{rpm}$. Before applying hydrogen gas, the reactor vessel was flushed repeatedly with nitrogen gas.

\subsection{Material}

The initial xylan (from birchwood, Roth, CAS: 014-63-5) concentration for each experiment was $1 \mathrm{wt} \%$ with respect to the moderate solubility of xylan in water and better comparability to other research studies on xylan conversion.

The concentration of the enzymes was varied between 1 and $10 \mathrm{ml} / \mathrm{kg}$. Various commercial enzyme preparations were used: Accellerase XY (DuPont) and an enzyme mixture containing the enzymes Ecopulp TX-800 A (AB Enzymes $\mathrm{GmbH}$ ) and Viscoferm (Novozymes A/S) (Eco/Vis mix), with $80 \mathrm{vol} \%$ and $20 \mathrm{vol} \%$, respectively. Ecopulp TX-800 A is a commercial enzyme (enzyme complex produced by nonpathogen fungi) with thermostable xylanase that exhibits an activity above 760,000 TXU/g (total xylanase units, measured via birchwood xylan). The suggested working range for Ecopulp TX-800 A is between 50 and $85{ }^{\circ} \mathrm{C}$ and $\mathrm{pH} 5-8$. Accellerase $\mathrm{XY}$ is another commercial enzyme complex in almost the same working range $\left(50-75^{\circ} \mathrm{C}, \mathrm{pH} 4,5-7\right)$, produced from the genetically modified fungi Trichoderma reesei. Its activity is documented as $20,000-30,000 \mathrm{ABXU} / \mathrm{g}$ (acid birchwood xylanase units). Viscoferm is also a commercial enzyme, but information is unfortunately relative scarce. The documentation claims that it mostly consists of $\beta$-Glucanase (cleavage of glucans $=$ glucose polysaccharides), but it additionally exhibits xylanase activity.

The Ru/C catalyst (5 wt\% Ru on Activated Carbon powder, Alfa Aesar, CAS: 7440-18-8) was dried and activated before process application. Drying was carried out at $140{ }^{\circ} \mathrm{C}$ and 5 bar nitrogen gas pressure for at least $3 \mathrm{~h}$. Subsequently, the catalyst was activated via reduction by hydrogen at the same temperature and 10 bar pressure. The activated catalyst was then stored in an air-tight and dry glassware container. The experiments were conducted with a catalyst loading of $1.5-3 \mathrm{~g} / \mathrm{kg}$ in the reaction solution.

\subsection{Analysis}

For the determination of xylanase activity of the samples, the reaction mixture containing $20 \mu \mathrm{l}$ of the sample and $180 \mu \mathrm{l}$ of $2.5 \%$ (w/v) xylan in $50 \mathrm{mM}$ citrate buffer (pH 4.8) was incubated for $20 \mathrm{~min}$ at $50{ }^{\circ} \mathrm{C}$. The reducing groups released after the incubation period were measured by the 3,5-dinitrosalicylic acid (DNS) method of Miller [15], using D-xylose as standard, and calculated with the corresponding calibration curve. One unit of xylanase activity (U) was defined as the amount of enzyme that produces $1 \mu \mathrm{mol}$ of reducing sugars per minute under conditions used in xylanase assay.

The carbohydrate and the monomer content of the samples were analyzed via a Smartline ${ }^{\circledR}$ HPLC of the company Knauer GmbH. It was equipped with a RI- and a UVdetector. For analysis of hemicelluloses and their conversion products, a 'sugar column' was installed to the RI detector (Smartline ${ }^{\circledR}$ RI 2300). The column line consisted of a precolumn (Eurokat-Pb $30 \times 8 \mathrm{~mm}, 10 \mu \mathrm{m}$ ) and a separation column (Knauer $\mathrm{GmbH}$, model Eurokat-Pb $300 \times 8 \mathrm{~mm}$, $10 \mu \mathrm{m}$ ); both were located inside a column oven (Jetstream 2). During each sample analysis, $20 \mu \mathrm{l}$ of sample was injected; the eluent was water (purified, degassed) with a flow rate of $0.6 \mathrm{ml} / \mathrm{min}$. The column oven was set to $75^{\circ} \mathrm{C}$ temperature. Typical analysis duration of one sample was $60 \mathrm{~min}$. In between the experiment samples, clear water was injected as intermediate clean- and rinse-run at the same conditions for at least $20 \mathrm{~min}$.

\section{Results and Discussion}

The first experiments were conducted with an enzyme mixture of Ecopulp TX-800A and Viscoferm enzymes. The aim was to investigate if any positive effects regarding xylose inhibition of the enzymes may occur at usual condition of the two sub-processes (hydrolysis and hydrogenation). Therefore, the process was operated in a 2-step mode wherein enzymatic hydrolysis was conducted at optimal reaction conditions (low shear-stress at $250 \mathrm{rpm}, 50{ }^{\circ} \mathrm{C}, \mathrm{p}=\mathrm{atm}$ ). After $24 \mathrm{~h}$ of hydrolysis the subsequent hydrogenation was carried out at process conditions of $10 \mathrm{bar}, 140{ }^{\circ} \mathrm{C}$ with gas-entrainment stirrer at $750 \mathrm{rpm}$. The elevated pressure of 10 bar is necessary when working with gaseous hydrogen, to increase the $\mathrm{H}_{2}$-solubility in the reaction solution, according to henry's law. Instead of the more common higher values of 40-60 bar $\mathrm{H}_{2}$ pressure [13], the window of process 
parameters was intendedly shifted towards more moderate reactions conditions to reduce the process-induced enzyme deactivation.

The first results of this combination of an enzyme-mixture with precious metal catalyst $(\mathrm{Ru} / \mathrm{C})$ to realize hydrolytic hydrogenation of xylan to xylitol are shown in Figs. 1 and 2.

The results of the xylan conversion with 5 and $10 \mathrm{ml} / \mathrm{kg}$ of enzyme mixture and subsequent hydrogenation show that double amount of enzymes leads to significantly faster cleavage during the first $7 \mathrm{~h}$. However, this difference diminishes over time, as indicated at $24 \mathrm{~h}$ of reaction time. In presence

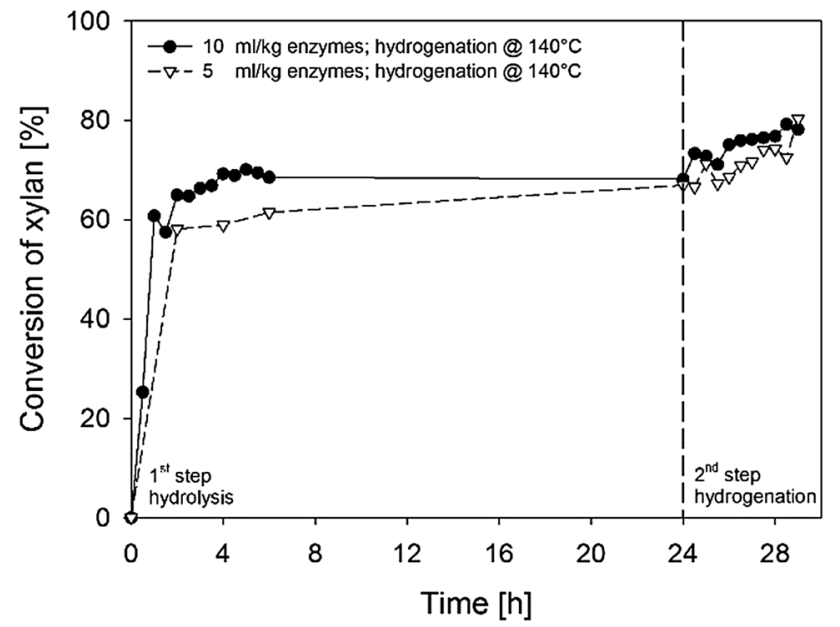

Fig. 1 Xylan (1 wt \%) conversion via two-step process with different enzyme loadings (Eco/Vis mix, $250 \mathrm{rpm}, 50{ }^{\circ} \mathrm{C}$, atmospheric) during the 1 st step $24 \mathrm{~h}$ and hydrogenation at $140{ }^{\circ} \mathrm{C}$ during 2 nd step $4 \mathrm{~h}$ at 10 bar $\mathrm{H}_{2}$ in the presence of $3 \mathrm{~g} / \mathrm{kg} \mathrm{Ru}$ catalyst ( $5 \mathrm{wt} \% \mathrm{Ru}$ on act. C)

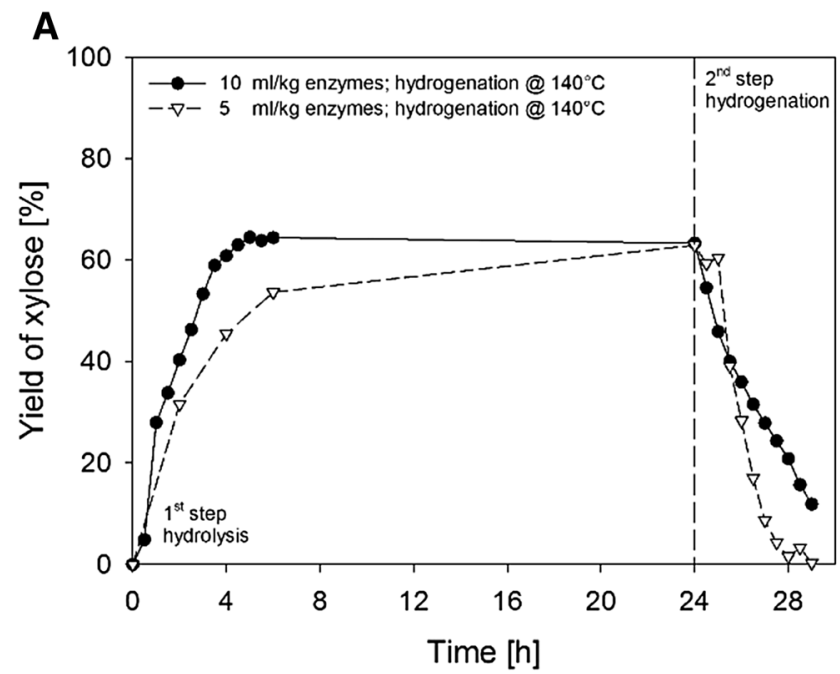

Fig. 2 Xylose production (a) and conversion to xylitol (b) via 2-step process with different enzyme loadings (Eco/Vis mix, $250 \mathrm{rpm}$, $50{ }^{\circ} \mathrm{C}$, atmospheric) during the 1 st step $24 \mathrm{~h}$ and hydrogenation dur- of $10 \mathrm{ml} / \mathrm{kg}$ enzymes, a plateau of xylan conversion (70\%) is reached after ca. $4 \mathrm{~h}$. A control experiment without enzymes showed that no xylan was converted to xylose under the chosen hydrolysis conditions, so that the conversion to xylose was definitely caused by the investigated enzymes.

During the 2 nd process step at 10 bar and $140{ }^{\circ} \mathrm{C}$, in presence of $\mathrm{H}_{2}$ and $\mathrm{Ru} / \mathrm{C}$ catalyst, the xylan conversion increases by $<10 \%$. This rise is relatively small. It was observed in previous studies (results not shown) that enzymes are deactivated at elevated pressures and stirrer speed (and high temperatures), therefore the increasing xylan conversion from 24 to $28 \mathrm{~h}$ could be explained by both some remaining enzyme activity or chemical autohydrolytic effects [16].

The maximum xylose yield of $65 \%$ during the hydrolysis of xylan with $10 \mathrm{ml} / \mathrm{kg}$ enzyme mixture is achieved at $5 \mathrm{~h}$ reaction time whereas the process with half the amount of enzymes, was slower, as expected, converting only $54 \%$ after $6 \mathrm{~h}$ (see Fig. 2) and 65\% after 24 h. As soon as the hydrogenation process begins at $24 \mathrm{~h}$, xylose conversion to xylitol is realized in relatively short time $(4 \mathrm{~h})$.

Interestingly, the $\mathrm{Ru}$-catalyzed hydrogenation reaction was impeded by the higher enzyme loading of $10 \mathrm{ml} / \mathrm{kg}$, reaching only $53 \%$ xylitol yield (based on initial xylan). The hydrogenation process in presence of $5 \mathrm{ml} / \mathrm{kg}$ enzymes achieved full conversion of xylose to xylitol with overall yield of $67 \%$.

To improve the elucidation of the xylose-induced product inhibition of the enzymes and the subsequent resolving via hydrogenation of xylose to xylitol, another enzyme preparation was selected for further experiments and the process conditions of the different steps were adjusted. Again, the process operation was a two-step mode where the first $24 \mathrm{~h}$

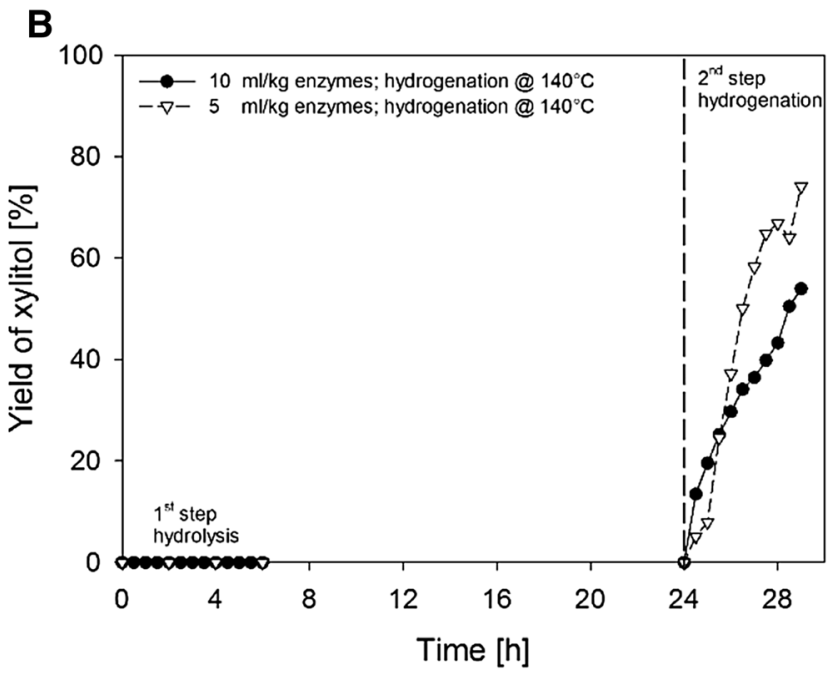

ing 2 nd step $4 \mathrm{~h}$ at 10 bar $\mathrm{H}_{2}$ in the presence of $3 \mathrm{~g} / \mathrm{kg} \mathrm{Ru}$ catalyst (5 wt\% Ru on act. C) 
reaction time were conducted at very moderate conditions to maximize the enzymatic hydrolysis until reaching its xyloseinduced inhibition. For this purpose, the temperature was slightly increased to $60{ }^{\circ} \mathrm{C}$ and the stirrer speed reduced to $100 \mathrm{rpm}$. Subsequently, the process parameters were elevated to more typical hydrogenation conditions $\left(70-100{ }^{\circ} \mathrm{C}\right.$, 10 bar, 750 rpm) (see Fig. 3).

The graphical results indicate a direct link between higher enzyme concentration and higher conversion rate and higher maximum conversion (for the first $24 \mathrm{~h}$ ). Interestingly, with the relatively high enzyme loadings of $5-10 \mathrm{ml} / \mathrm{kg}$ a plateau of conversion is reached after ca. 1-2 h of treatment; during the following process duration of the 1st step, no significant change of conversion was noted. However, at a lower enzyme loading of $2.5 \mathrm{ml} / \mathrm{kg}$ a small but steady increase in conversion of xylan was observed during the first $24 \mathrm{~h}$. Afterwards, when hydrogenation of xylose to xylitol started (in the presence of $\mathrm{Ru} / \mathrm{C}$ catalyst), the xylan conversion increase to overall values of approx. $80 \%$. The observed plateau and sudden conversion increase indicates that a product-inhibition existed. The enzymes resumed xylan cleavage as soon as xylose was converted to xylitol (see Fig. 3). However, the strongest conversion gain was noted during the very moderate $70{ }^{\circ} \mathrm{C}$ hydrogenation process. Temperatures above $90{ }^{\circ} \mathrm{C}$ caused rapid thermal deactivation of the enzymes. The deactivation of the $\mathrm{Ru} / \mathrm{C}$ catalyst additionally still remains an issue and could not yet be overcome by any in situ measures. It has been reported elsewhere that catalyst deactivation is a significant problem when working with lignocellulosic components [17]. However, the catalyst material of our studies was recollected and reactivated via high Temperatures and hydrogen-reduction (see chapter material).

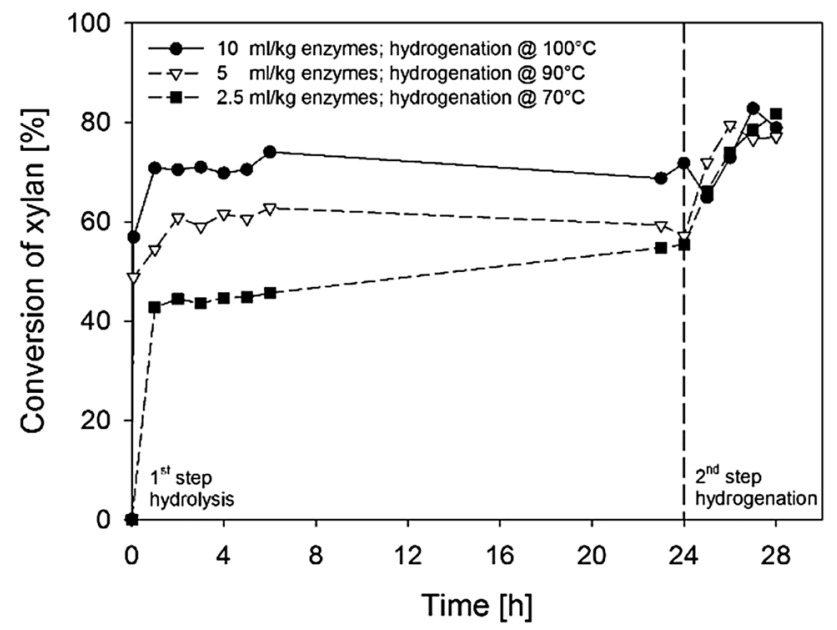

Fig. 3 Xylan (1 wt\%) conversion via 2-step process with different enzyme loadings (AccelleraseXY, $100 \mathrm{rpm}, 60^{\circ} \mathrm{C}$, atmospheric) during the 1 st step $24 \mathrm{~h}$ and temperature variation for the 2 nd step $4 \mathrm{~h}$ of hydrogenation at 10 bar $\mathrm{H}_{2}$ with $2 \mathrm{~g} / \mathrm{kg} \mathrm{Ru}$ catalyst (5 wt\% Ru on act. C)
Regardless of the enzyme loadings and the subsequent hydrogenation temperature, the maximum xylan conversion was always about $80 \%$. A kind of equilibrium state, which also occurred when using other enzyme preparations during the first experiments (see Figs. 1, 2). A complete conversion of xylan using $\mathrm{Ru} / \mathrm{CNT}$ catalysts was found in experiments by Ribeiro et al. [18] observed at temperatures above $170{ }^{\circ} \mathrm{C}$ at a pressure of 50 bar. However, the physical reaction conditions were significantly different (much higher $\mathrm{T}$ and $\mathrm{p}$ ) and the reported catalyst-substrate-ratio (c/s) was 0.4 and therefore about twice as high as compared to the at hand studies $(\mathrm{c} / \mathrm{s}=0.2)$. This smaller $\mathrm{c} / \mathrm{s}$ value was selected, as previous studies [16] showed that a c/s ratio of $0.15-0.3$ is suitable for hydrogenation of the xylanhydrolysate xylose to xylitol. Another argument for decreased $\mathrm{Ru} / \mathrm{C}$ catalyst loading was the assumption, that too much catalyst may cause enzyme deactivation due to adsorption on the amorphous catalyst carrier (activated carbon powder). The dilute substrate concentration of $1 \mathrm{wt} \%$ is very common in relevant reported research $[8,13,17]$ and can be explained by solubility issues of lignocellulosic compounds in water and by the desire to limit the required amount of catalyst. The selected ratio of enzymes to substrate of $0.25-1$ is also based on literature values [19] and preliminary experiments (not shown). However, our results show (see Figs. 2, 4) that the ratio of Ru/C versus enzymes strongly influences the xylose and xylitol production. There is strong potential for future optimization, because too high concentration of either one of the catalysts should be avoided to minimize the deactivation of the other respective catalyst.

While the xylan conversion remained stable on a level about $80 \%$ regardless of the enzyme loadings, the yield of xylose showed clear differences between the various enzyme loadings. At low enzyme loadings, there was an unfavorable ratio between available enzymes and substrate, so that the turnover rate was reduced and less xylose was formed (see Fig. 4a). The majority of xylose was formed mainly in the first 4-6 h.

The product yield curves of xylose and xylitol, combined with the xylan data, prove the xyloseinduced product inhibition of Accellerase XY and show how a subsequent (or preferably immediate) conversion of xylose can overcome this issue. As seen in Fig. 4b with regard to the xylitol yields, there is a clear dependency of temperature and xylitol formation. Only at $100{ }^{\circ} \mathrm{C}$ a complete hydrogenation of xylose was achieved within $4 \mathrm{~h}$. Therefore, for a future optimization of the process parameters of both sub-processes the kinetics of delayed xylitol formation at temperatures below $100{ }^{\circ} \mathrm{C}$ must be intensively investigated in further studies.

As described in the experiments above, a large part of the xylan is hydrolyzed in the first few hours. In order to meet the goal of simultaneous enzymatic hydrolysis and chemocatalytic hydrogenation, in the following experiment, the 


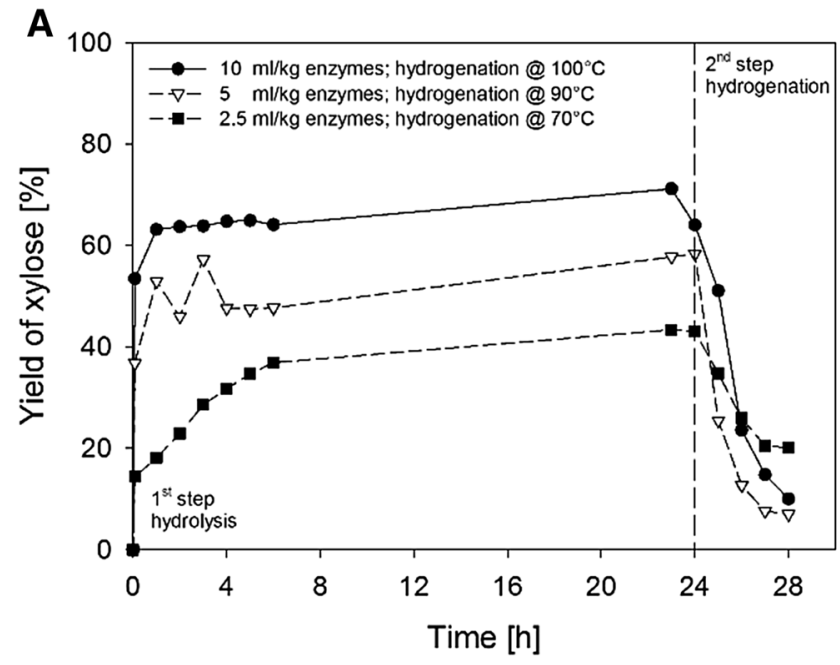

Fig. 4 Xylose production (a) and conversion to xylitol (b) via 2-step process with different enzyme loadings (AccelleraseXY, $100 \mathrm{rpm}$, $60{ }^{\circ} \mathrm{C}$, atmospheric) during the 1 st step $24 \mathrm{~h}$ and temperature varia-

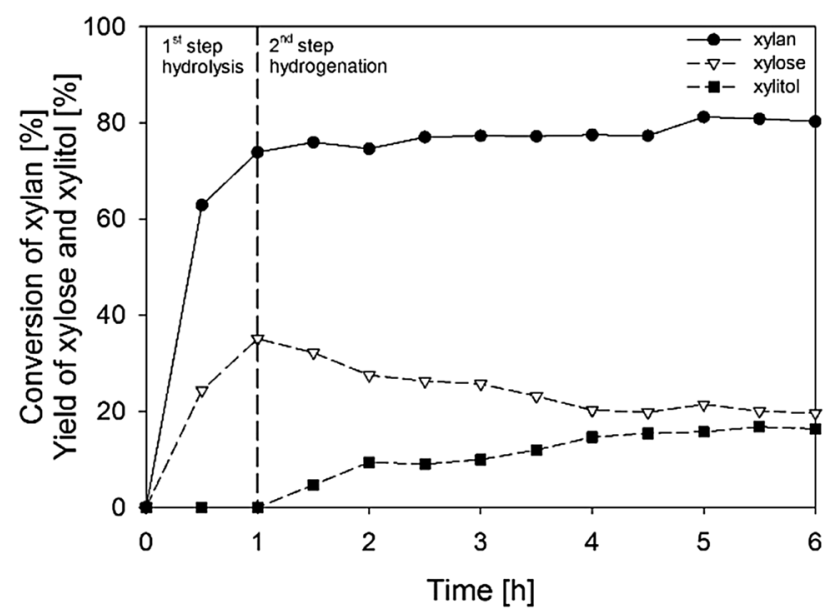

Fig. 5 Xylan conversion via 2-step process (Eco/vis mix, $250 \mathrm{rpm}$, $50{ }^{\circ} \mathrm{C}$, atmospheric) during 1 st step $1 \mathrm{~h}$ and hydrogenation during $2 \mathrm{nd}$ step $5 \mathrm{~h}$ at $90{ }^{\circ} \mathrm{C}$ and $10 \mathrm{bar} \mathrm{H}_{2}$ in the presence of $3 \mathrm{~g} / \mathrm{kg} \mathrm{Ru}$ cat. (5 wt\% Ru on Act. C)

time of the pure hydrolysis at $50{ }^{\circ} \mathrm{C}$ was shortened to $1 \mathrm{~h}$. Then, the temperature was increased to $90{ }^{\circ} \mathrm{C}$, the maximum usable temperature due to the thermal deactivation of the enzymes even if this is not optimal for hydrogenation (see Fig. 5).

The results of the experiment on enzymatic hydrolysis at $50{ }^{\circ} \mathrm{C}$ with subsequent $\mathrm{Ru}$-catalyzed hydrogenation at $90{ }^{\circ} \mathrm{C}$ show only small increase in xylan conversion from $74 \%$ at $1 \mathrm{~h}$ to an end conversion of ca. $80 \%$. This appears to be maximum possible conversion, which could not be changed by the given conditions (temperature $<100{ }^{\circ} \mathrm{C}$, pressure $<10$ bar) either by higher enzyme loadings or by a

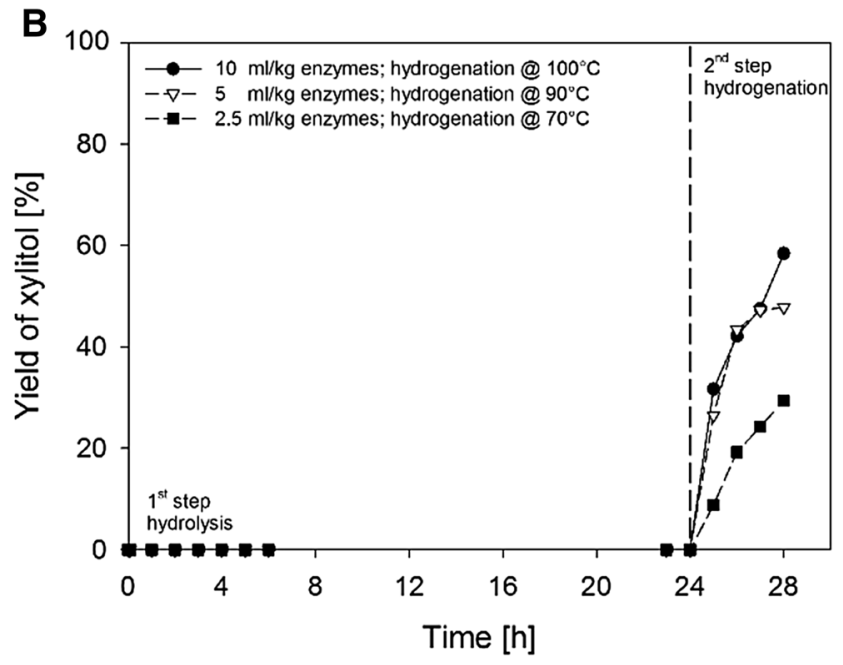

tion for the 2nd step $4 \mathrm{~h}$ of hydrogenation at 10 bar $\mathrm{H}_{2}$ with $2 \mathrm{~g} / \mathrm{kg} \mathrm{Ru}$ catalyst (5 wt\% Ru on act. C)

timely hydrogenation of the xylose. Xylan consists of up to 13\% glucuronic acid (according to xylanase provider Megazyme) linked to xylose, where most xylanases seem to be unable to cleave this bond [20]. Furthermore, autohydrolytic catalysis can cleave hemicelluloses to monomer-oligomer mixtures but the overall hydrolysis typically remains incomplete [21].

In contrast to the previous experiments, the xylan was cleaved only partially to xylose, whereas after the earlier 24-h hydrolysis almost complete conversion was achieved. Regarding the xylan and xylose data past $1 \mathrm{~h}$, it can be assumed that no significant amount of xylose was further produced during the hydrogenation phase. Hence, a sustained increase in temperature to $90{ }^{\circ} \mathrm{C}$ resulted in inactivation of the enzymes within a very short time. Furthermore, the low hydrogenation temperature led to a very low yield of xylitol (16\% based on initial xylan).

Despite the low conversion of xylose to xylitol at low temperatures for hydrogenation below $100{ }^{\circ} \mathrm{C}$, a final concluding experiment was conducted to test the combination of bio- and chemo-catalysis in the same one-step process and reactor. For this, the temperature was set in favor of the hydrolysis to $60{ }^{\circ} \mathrm{C}$, while the stirring speed was adjusted to $1000 \mathrm{rpm}$ and the pressure to $20 \mathrm{bar}$ in favor of hydrogenation. The results are shown in Fig. 6.

The one-step process at low temperature of $60{ }^{\circ} \mathrm{C}$, with high pressure and stirring speed right from the beginning shows a xylitol yield below 20\% after $8 \mathrm{~h}$. This is very low compared to the existing industrial process using RaneyNickel catalysts. Here, xylitol yields of 50-60\% are achieved (based on xylan) at $140{ }^{\circ} \mathrm{C}$ and 50 bar [22, 23]. However, in contrast to the shortened 2-step process (Fig. 5) a steady 


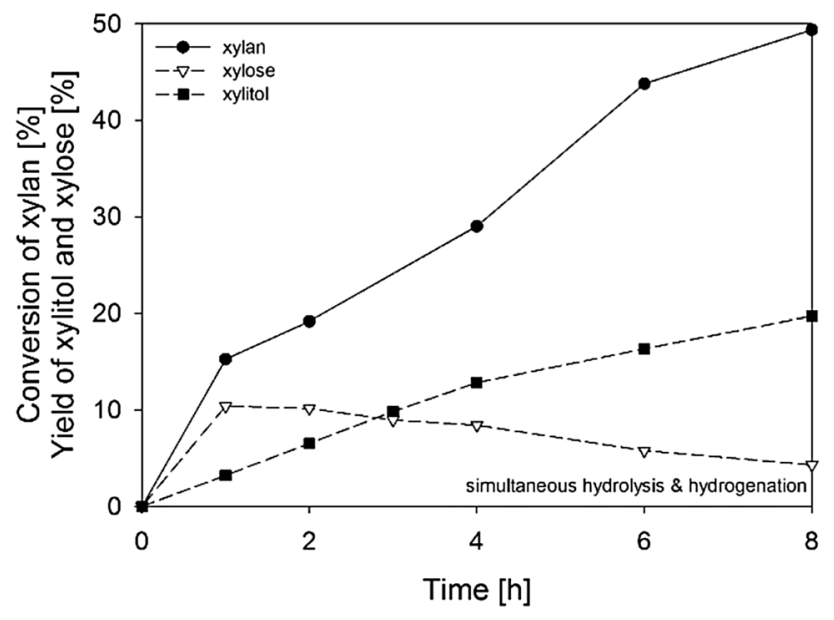

Fig. 6 One-pot enzymatic hydrolysis of xylan and chemical hydrogenation of xylose to xylitol $\left(0.5 \mathrm{ml} / \mathrm{l}\right.$ Accellerase $\mathrm{XY}, 20$ bar $\mathrm{H}_{2}$, $1.5 \mathrm{~g} / \mathrm{l} \mathrm{Ru} / \mathrm{C}$ (5 wt.\% Ru on Act.C), $60{ }^{\circ} \mathrm{C}, 1000 \mathrm{rpm}$ )

increase in xylan conversion and xylitol production can be observed. This means that under the chosen conditions both the enzymes and the chemical catalysts are able to work and the experiment has shown that an implementation of a onestep process in one-pot is possible at very moderate process conditions, with potential for energy and resource savings.

\section{Conclusion}

In all investigated experiments, the conversion of xylan was about $80 \%$, which was almost completely split into monomers (xylose) by enzymes at the 2 -step process with a hydrolysis of $24 \mathrm{~h}$. The conversion rate of $80 \%$ demonstrated a maximum, which could not be changed by the given conditions (temperature $<100{ }^{\circ} \mathrm{C}$, pressure $<10$ bar) either by higher enzyme loadings or by a timely hydrogenation of the xylose and the related reduction of xylose-indicated product inhibition through subsequent product conversion. Possible explanations for this observation were discussed. Furthermore, it was shown that hydrogenation of xylose to xylitol is possible even at low temperatures $\left(<90{ }^{\circ} \mathrm{C}\right)$, whereby temperatures above $100{ }^{\circ} \mathrm{C}$ led to complete conversion of xylose to xylitol within $4 \mathrm{~h}$. An adaption of temperature in favor of the enzymatic hydrolysis had a positive effect on the process and enabled simultaneous hydrolysis and chemo-catalytic hydrogenation in one reactor.

The experiments were dedicated to push open the window towards progressive process concepts that try to combine enzymatic and chemo-catalytic reaction pathways in an advantageous manner. The interplay between product-inhibition, temperature- and pressure-induced enzyme deactivation and chemical reaction kinetics showed a complex dynamic. Potential advantageous process conditions could evolve from the 2-step process concept, given the right ratio between reactant, enzyme and precious metal catalyst. The reaction time and temperature for the two process steps offer strong possibilities for process optimization.

Acknowledgements Funding from Technische Universität Dresden, Faculty of Mechanical Engineering via the "Eigenforschung" program is gratefully acknowledged. In addition, the authors thank the EU for funding of the project "CrossCat" supported by EFRE Program (ERA-IB) of Sächsisches Staatsministerium für Wissenschaft und Kunst (SMWK, Grant No. 100271549)

\section{Compliance with Ethical Standards}

Conflict of interest The authors declare that they have no conflict of interest.

Open Access This article is distributed under the terms of the Creative Commons Attribution 4.0 International License (http://creativeco mmons.org/licenses/by/4.0/), which permits unrestricted use, distribution, and reproduction in any medium, provided you give appropriate credit to the original author(s) and the source, provide a link to the Creative Commons license, and indicate if changes were made.

\section{References}

1. Boussarsar HB, Rogé B, Mathlouthi M (2009) Biores Technol 100(24):6537-6542

2. Brecker L, Wicklein D, Moll H et al (2005) Carbohydr Res 340(4):657-663

3. Kim KH, Tucker MP, Keller FA et al (2001) Appl Biochem Biotechnol A 91(1):253-267

4. Leppänen K, Spetz P, Pranovich A et al (2011) Wood Sci Technol 45(2):223-236

5. Rehman MSU, Kim I, Kim KH, Han JI (2014) Int J Environ Sci Technol 11(2):543-550

6. Anwar Z, Gulfraz M, Irshad M (2014) J Radiat Res Appl Sci 7(2):163-173

7. Rafiqul ISM, Mimi Sakinah AM (2013) Food Rev Int 29:127-156

8. Kusema BT, Hilpmann G, Mäki-Arvela P et al (2011) Catal Lett 141:408-412

9. Hilpmann G, Becher N, Pahner F et al (2016) Catal Tod 259(2):376-380

10. Borges TA, de Souza AT, Squina FM et al (2014) Process Biochem 49(1):77-83

11. Paës G, Berrin JG, Beaugrand J (2012) Biotechnol Adv 30(3):564-592

12. Chattopadhyay SU, Raychaudhuri U, Chakraborty R (2014) J Food Sci Technol 51(4):611-621

13. Mäki-Arvela P, Salmi T, Holmbom B et al (2011) Chem Rev 111(9):5638-5666

14. Walther T, Ostermann K, Listewnik HF et al (2002) German Patent DE 10222373.4-42

15. Miller GL (1959) Anal Chem 31(3):426-428

16. Hilpmann $G$ (2017) Process Intensification via Catalytic One-Pot Conversion of Hemicelluloses to Sugar-Alcohols. PhD Technische Universität Dresden, Dresden

17. Fabičovicová K, Malter O, Lucas M, Claus P (2014) Green Chem 16:3580-3588

18. Ribeiro LS, Delgado JJ, Melo Órfao JJ, Pereira MFR (2016) RSC Adv 6:95320-95327

19. Dumon C, Song L, Bozonnet S, Et al (2012) Proc Biochem 47(3):346-357 
20. Puls J, Sinner M, Dietrichs HH (1978) Starch 30(9):294-299

21. Salmi T, Murzin DY, Mäki-Arvela P et al (2014) AIChE J 60(3):1066-1077

22. Herrera VAS, Oladele O, Kordás K, et al (2011) J Chem Technol Biotechnol 86(5):658-668
23. Déchamp N, Gamez A, Perrard A, Gallezot P (1995) Catal Today 24(1-2):29-34 